\title{
Rethinking Techno-Social Interaction(s) through the Lens of Technorealists
}

\author{
Hüseyin Tolu
}

\begin{abstract}
Societies are on the way to becoming smarter every day by following, copying, and observing one another; the increase of knowledge is already accelerating, but do we know what all of us know? Or more critically, are we able to benefit from everything one has learned? The literature normatively postulates techno-social interactions to be a multi-motivated and multi-consequential phenomenon driven by imbalances in economic, social, cultural, and political situations (non-philosophical facts). Nevertheless, the literature has not highlighted its modern sociological assumptions; it acts as a Techno-utopianist (Nietzschean thoughts) or at least as a dominated technological-determinist (Giant wishes). In this sense, this study takes a different approach to analyzing techno-social interactions using the principles of Technorealism to discuss the issues that concern Technorealists. This paper argues that Technorealists wish to break loose from being pure modern technophiles whose revolts, freedoms, and passions are governed by techno-social struggles. The paper shall metaphorically envisage the extent to which current and future controllers should be avoided without taking any peculiar postmodern moral objective (e.g., stop surveillance governance).
\end{abstract}

Keywords: Sociology of technology, technological determinism, technorealism, education of technology, philosophy of technology.

Öz: Günümüz toplumları birbirlerini takip ederek, gözlemleyerek, kopyalayarak her gün daha akıllı olma yolundalar; bilgi artışı zaten hızlanıyor ama hepimizin ne bildiğini biliyor muyuz? Ya da daha eleştirel olarak, birinin öğrendiği her şeyden yararlanabilir miyiz? Günümüzün literatür, tekno-sosyal etkileşim(leri) ekonomik, sosyal, kültürel ve politik durumların dengesizlikler tarafından yönlendirilen çok motive ve çok yönlü bir normatif fenomen olarak yorumlamaktadır (felsefi olmayan gerçekler). Bu çalışmayla beraber, yine de, geçerli literatür, "modern" sosyolojik varsayımları vurgulamamakta, bir Tekno-ütopyacı (Nietzschean düşüncesi) veya en azından egemen bir teknolojik-determinist (Devlerin dilekleri) olarak hareket etmektedir. Bu bakış açısıyla, bu çalışma Teknokalistler ile ilgili sorunları tartışmak için Teknokalizm ilkeleriyle tekno-sosyal etkileşimi analiz eden farklı bir yaklaşım benimsemiştir. Bu makale, Teknokratikçilerin isyanı, özgürlüğü ve tutkusu tekno-sosyal mücadelelerle yönetilen saf "modern" teknisyenler olmaktan kurtulmak istediklerini savunuyor. Bu çalışmada, yeni teknolojik alan bakış açlların bir tuhaf "postmodern" ahlaki amaç (ör. Gözetim yönetişimini durdurma) almadan mevcut ve gelecekteki kontrolörlerden kaçınmamız gerektiğini mecazi olarak öngörecektir.

Anahtar Kelimeler: Teknolojinin sosyolojisi, teknolojik determinizm, teknorealizm, eğitim teknolojisi, eğitim felsefesi. 


\title{
Introduction to Current Sociology
}

\author{
Now, here, you see, it takes all the running you can do, to keep in \\ the same place. If you want to get somewhere else, you must run \\ at least twice as fast as that! \\ L. Carroll-Alice through the Looking Glass
}

Societies get smarter every day by following, copying, and observing; the increase of knowledge is already accelerating, but do all of us know what one knows? Or more critically, are we able to all benefit from what someone has learned; do we have cosmopolitan knowledge? But what are its benefits? Is it pellucid to have any peculiar benediction or invocation in this age of knowledge? Aside from how fast we have to work, is the best scenario to reach others desirably for now at least and/ or mischievously at most to pass others for the future, or is it best to first reach out and grab them and second to hold onto them whatsoever? Shall we then re-question just once more what techno-social interactions are or indeed should be? Nevertheless, what is clear is that:

The technologist must be held not only technically but also morally responsible for whatever he designs or executes: not only should his artefacts be optimally efficient but, far from being harmful, they should be beneficial, not only in the short run but also in the long term. (Bunge, 1977, p. 99)

For the e, z, cyber, virtual and/or digital generations, the actual matter of techno-social interactions then will never focus on what technology is really all about but what the best way would be to approach technology. No precise definition exists for technology due to its evolving and diversified nature, and as such so has its definitions. The indisputable reality is that technology also has inevitably and unpredictably evolved the human life cycle. Throughout the social sciences, technology is normatively (epidemically) approached as an omnipotent panacea by techno-social Darwinists and/or over-Humanists (or Ubermensch by Nietzscheans) in the Age of Singularity. However, the narrative of techno-social interactions cannot be accompanied unless we have a heart for the other side, Neo-Luddism, which perceives particular (not all) technologies as a diseased virtue in the age of Golden Junk (prioritizing the earth, humans, and then what is man-made). In this sense, agreements about studying these approaches cannot be judged without facing struggles about the nature and scope of techno-social interactions (henceforth TSIs). Nevertheless, the actual matter is not what TSIs are, but rather what TSIs are for! It is a conceptualized phenomenon in academia but has it been deliberately overtaken (or misled) by politicians, giants, and so forth? In other words, it is not 
just about the definition of TSIs but more likely about the implications of its definition. Whether or not its implications have furtively devalued our lives and not just the world we actually live in, does it then really matter as such to have a perfect (hypersurveillant) governing mechanism, as William Bogard (1996, p. 55) said so well: Simulated governance is beyond the panopticonic Big Brother, which "is nothing less than perfect surveillance, surveillance raised to the highest power, where nothing escapes the gaze. Everything already observed, absolute foreknowledge of events grounded in the possession of the codes which generate them."

To start with this, over 16 million web pages exist in general areas of the online world and over 1 million web pages in academia that include TSIs as a topic (using a search engine). TSIs are postulated as a multi-motivated and multi-consequential phenomenon driven by the imbalances of (mainly) economic, social, cultural, and political facts (non-philosophical facts); nevertheless, the literature does not highlight its modern sociological assumptions (e.g., stringencies) but acts as a techno-utopianist (Nietzschean thoughts), or at least as a dominated technological determinist (Giant wishes). Fundamentally, TSIs are claimed to exist in the disparities between those who use technology and consequentially benefit from this usage and those who do not use technology. Achieving these benefits is seen as equally important as achieving fundamental human needs such as food and water. This study thereby takes a slightly different approach from the norm toward considering TSIs by using Technorealism as a reminder of what concerns Technorealists. Notably, this particular study has been accomplished using the approach of a literature review essay.

\section{Technology-Determinism vs. Neo-Luddism}

According to Pool (1983, p. 5), “The relationship between technology and institutions is not simple or unidirectional, nor are the effects immediate. Institutions that evolve in response to one technological environment persist and to some degree are later imposed on what may be a changed technology." Even though the standpoint of Pool is primarily a soft technological determinist one and sociologically admissible within the latest technological innovations such as computers and the Internet, public opinion has been propagated by hard technological determinism; for instance, Bill Gates (1996) claimed that current technology is politically and sociologically non-evaluative because it is neutral to mutually public schools. The Internet is for illumination, enlightenment, and liberation, and the computer 
is purely an essential and necessary artifact that is very able or competent for a practical purpose.. Technological determinists stand upon two central approaches:

(1) The nature of technologies and the direction of change were unproblematic or pre-determined (perhaps subject to an inner technical logic or economic imperative); (2) technology had necessary and determinate impacts upon work, upon economic life, and upon society as a whole; technological change thus produces social and organizational change. (Williams \& Edge, 1996, p. 860)

Nevertheless, the approaches of technological determinists underestimate TSIs regarding which particular technologies (not all) are problematic; those that are necessary have not been at all determined. For instance, current technology has publicly been used as a shy, fearful, but legitimized tyrant because of its known and unknown corruption in the sense of its own context matter, such as surveillance tools. Indeed it all depends on our political-philosophical approach, which defines whether someone exists as a legitimated tyrant or not and, as such, do not believe in The Tale of the Slave by Robert Nozick (1974). But an analysis of this argument is beyond the purposes of this study The main motivation from technological determinists lacks how to ascertain how technology will react to TSI-related issues without generating (or being another reason for) comparatively precarious issues. Many are thereby insightful toward technology, its confusing ally of globalization, and all its resultant consequences that consist of global warming to cyber-wars, such as few have revealed. Therefore, the standpoints of technological determinists are normatively at the top in supporting all technology, but they are not seen to touch upon technology apart from its fundamental technological necessity. As such, they have no certainty or particular value in terms of techno-social pleasures or delights whatsoever.

In modern life, "You have to hate the computer to use it well; there is no other choice. In any other choice, you are becoming a fool and you are wasting your time" (Lanier, 2012, p.28-29). From the point above, Neo-Luddites contend that technological improvements are outcomes and consequences of interactions between technology and society, but social forces should govern the direction of technological innovations in the first place. Indeed, this is the same exclamation from social determinism (Winston, 1998). The technological process, in particular its innovation and inventions in its own unique content, cannot rely on a simple technological rationality as a logical reasoning of best-ness (e.g., quality or state of being the best options and choices), rather it can rely on the surrounding substance of logic in terms of the best options and choices that are primarily shaped and pictured 
by social forces. Emerging technology has placed itself into a particular society if that society has a particular necessity (needs and desires). In terms of unbounded social forces, Neo-Luddism is principally "a leaderless movement of passive resistance to consumerism and the increasingly bizarre and frightening technologies of the Computer Age" (Sale, 1996). In this connection, advocates of Neo-Luddism are not simply being like the Amish, who are against contemporary technology due to their religious beliefs (e.g., technological temptation), or like technophobes, who have anxiety or fear of learning how to use modern technology (e.g., the riddles of technological complexity). In contrast, Luddites have a particular techno-social standpoint against certain technologies (not all); they are therefore extremely exceptional and unique groups that include and expand many other various margins such as human and animal rights and environmentalist groups. Admittedly, while some analysts criticize capitalism through democracy, their concern becomes purely political, but when techno-social interactions are criticized, the concern is more akin to political sociology (e.g., Heidegger, 1977). For instance, in the technological society, Ellul approached technology from a deterministic viewpoint, emphasizing technological governance over civilization and humankind and its likely risks to social freedom and liberty. Ellul observed technology (as a technique) as:

The only thing that technically matters is yield, production. This is the law of technique; this yield can only be obtained by the total mobilization of human beings, body and soul, and this implies the exploitation of all human psychic forces. (1964, p. 324)

Therefore, the fundamental idea of Neo-Luddism is that re-burgeoning technology is a splendid splendor, has remarkable potentials and trends with humans, but also has a detrimental and destructive pressure on individuals and environments perhaps due to current and future amphibolies.

Day by day, however, the machines are gaining ground upon us; day by day we are becoming more subservient to them; more men are daily bound down as slaves to tend them, more men are daily devoting the energies of their whole lives to the development of mechanical life. (Butler, 1863, p. 51)

For engineers, the main concern about techno-social interactions is to make practical details better and more useful through techno-determinist pragmatism, not for technology itself. Pragmatism in this sense is "a philosophical movement that includes those who claim that an ideology or proposition is true if it works satisfactorily, that the meaning of a proposition is to be found in the practical consequences of accepting it, and that impractical ideas are to be rejected" (McDer- 
mid, 2006). However, working satisfactorily does not guarantee the absence of any negative outcomes or consequences for the public (e.g., Boyle, 2008). In the case of "Information does not want to be free; people do" (Doctorow, 2013), working satisfactorily only works for the Giant, not the public people. The argument is that engineers know what technologies do but don't really care about knowing what technologies are for; these two are different conjunctions because of how societies and interactions are shaped in the first place after technology itself. Human beings make technological changes, and then policies are based on social, cultural, political, and economic values (e.g., market forces), not the other way around. If not, one might simply inquire why after a decade no international agreement or even consensus exists yet about Interoperability and specifically Software Interoperability Standards. Or why the Internet Treaty and Regulations of the International Telecommunication Union (ITU), PROTECT IP Act (PIPA), Stop Online Piracy Act (SOPA), Anti-Counterfeiting Trade Agreement (ACTA) and Cyber Intelligence Sharing and Protection Act (CISPA) or these kinds of arguments have now become the main global concerns. Or can we look at the Treaty on the Non-Proliferation of Nuclear Weapons; after 60 years is there an international agreement yet? No! Because these are all sociologically political; precedents may be multiplied when we ask if there are actual technological concerns.

Before we work on artificial intelligence, why don't we do something about natural stupidity? (Steve Polyak, 1889-1955).

In this sense, techno-ethics must exist that are clarified as:

...an interdisciplinary field concerned with all ethical aspects of technology within a society
shaped by technology. It deals with human processes and practices connected to technology
which are becoming embedded within the social, political, and moral spheres of life. It also ex-
amines social policies and interventions occurring in response to issues generated by technolo-
gy development and use. This includes critical debates on the responsible use of technology for
advancing human interests in society. (Luppicini, 2008, p. 4).

According to Hughes, "a technological system can be both a cause and an effect; it can shape or be shaped by society. As they grow larger and more complex, systems tend to shape society and be less shaped by it" (1994, p. 112). Regarding this, technology may change our understandings and behaviors about technology as an internal and external force. However, the power is understood to still remain in humans socially in the sense that as everything is social, so technology itself is sociological. All discussions are for better understanding technology and social sciences. Thus the author fundamentally aims to neither underline the best the- 
ory nor attempt to compare theories. The author has emphasized Neo-Luddism because understanding the role of power in non-human actors influences how we find actors to make systems better for the future. Therefore, we should discuss the case of technology and societies more by viewing the power that remains within us based on defined values. Importantly, "Modern machines are quintessentially microelectronic devices; they are everywhere and they are invisible. Modern machinery is an irreverent upstart god, mocking the Father's ubiquity and spirituality" (Haraway, 1985, p. 120). We are in separate, knowledge-based societies that have lain down on the dialectical commissure between technology and human. In other words, a powerful initiative, artifact and human, have reshaped each other to lead a better prospective future (Organisation for Economic Cooperation and Development, 1996). Beyond the piecemeal comparisons of technological approaches, as further argued, people believe the philosophy of Neo-Luddism to be an irreverent grandee goddess for validating and liberating our ubiquity and spirituality, to be the last bastion of emancipation in technological knowledge, and to be attempting to resist the current philosophy of technological determinism, which is the actual irreverent upstart goddess for negating and controlling us without taking any postmodern values (Morozov, 2011). In other words:

Why are we doing what we are doing? ... Because science and technology have seldom paused to explain their own dynamics, there is obviously much work to be done on this score. (Winner, 1989, p. 433)

In this sense, this paper individually admires and reveres the values of Neo-Luddites and Luddites; nevertheless we are in the Global-Political Economy and so Neo-Luddites must once more realign themselves with specific digital natures and realities. McCluskey provided eight principles (e.g., values) of techno-social-interactions conceptualizing Technorealism in which:

Technology is not neutral. The Internet is revolutionary but not Utopian. Government has an important role to play on the electronic frontier. Information is not knowledge. Wiring the schools will not save them. Information wants to be protected. The public owns the airwaves and the public should benefit from their use. Understanding technology should be an essential component of global citizenship. (1998)

Thus, Technorealism is an effort to increase the central view between Techno-determinism/Utopianism and Neo-Luddism by considering the social connotations of technologies so that the entire public may have more power of control for its own prosperity. As such, should we consider Walt Mossberg's words: "Why 
shouldn't a PC work like a refrigerator or a toaster? ...I'm an enemy of what I call 'computer theology.' There's a class conflict out there. There's a techno-elite that lives in a different world." From the brief argumentation of Technological Determinism, Neo-Luddism, and Technorealism, examining TSIs' indications might be helpful for demonstrating how important real-world issues have fruitfully been presented in the literature.

\section{Technorealists' Society}

Freedom is what you do with what's been done to you. Jean-Paul Sartre (1905-1980)

For posterity, the only phenomenon that will exist is that which has been done online. If it is not online, it will simply not exist. Nevertheless, introducing new technology reduces conventional social issues to a singular milieu because not only is burgeoning knowledge a peculiar panacea but also a camouflaged disease due to its singular nature. This singularity is seen in the very nature of the online milieu, a set of interior interactions among technology, politics, and administration in which each has a particular persistence of presence but develops a variety of complex interactions when integrated. As an emergent property, this would be referred to as cybernetics, the scientific study of control and communication in any system using technology (Wiener, 1964). Technorealist society is orchestrated for its own general political, social, cultural, and economic consequences by the emergent property of TSIs, but now new ethical (external and internal) TSI concerns exist regarding conventional democratic principles (Sourin, 2006), particularly freedom and liberty, because:

...civilization is impossible without traditions, and progress impossible without the destruction of those traditions. The difficulty, and it is an immense difficulty, is to find a proper equilibrium between stability and variability. (Gustave, 1896, p. 49)

Still, today's challenges are in equilibrium between globalism and localism with cybernetics, and no clear approach exists on how to face these as individual nation-states. What new democratic principles ought to be arrived at in this new equilibrium? Noticeably, the implementations of TSIs have very diverse insights into the struggle for equal opportunities in technology and their clarifications, but the literature so clearly has its modern sociological assumptions, acting as a Techno-Utopianist (Nietzschean ideas) or at the least dominated by the technological-determinists (Giant wishes). In this sense, technological determinists actually 
recognize that the trouble results from distortions of epistemology and associations with a particular society that serve the interests of the leading group (e.g., Giant). Within technology, these distortions arrive at the conclusion of the myth of technology being neutral with linked values. Many scholars (e.g., Oppenheimer, 2004) consider this myth and its values to possibly be unhelpful and obstructive in terms of individual dealings with technology and to set up concern, dread, isolation, and illogical and disincentive warnings about technology. Consequently, the difficulty of having equal opportunities in technology is not purely that of lost opportunities for some groups. The absolutist view of technology thereby constructs the difficulty as being for us all. In terms of the implications of TSIs for technological determinists, the importance is on examining a part of technology at all levels. The modern technological trekking, not the end, is the aim and objective. The literature thereby characterizes the most draconian shift presented by a modern Westerner as taking control of every aspect of TSIs and dictating their aspirations and desires (outcomes) as "the ideal of a stable society, expressed by objectively controllable social mechanisms ...it is no longer a question of predicting the future, but of reproducing the present. It is no longer a question of static order, but of a dynamic self-organization" (Tiqqun, 2010, pp. 9-18). However, "The technologies created and disseminated by modern Western societies are out of control and desecrating the fragile fabric of life on Earth" (Glendinning, 1990, p. 82).

Although the isolated features of applications may have present-day value, in view of the narrow choice of objections and the principles of the legislators and stakeholders who quite frankly wield control of the power, the general results are often extremely anti-human (without value). Conceptualizing TSIs proposes a rigid order of the content and means of considering TSIs; it nonetheless leaves its interconnections unspecified. A fundamental neutral view of technology is the techno-social cultural and political values that govern the modern Western systematic horizon. This is the horizon of reason that values rationality and rational decisions but degrades social loathing. Technological determinism perceives TSIs in terms of the obstacles faced by particular societies joining the techno-social world, which in their view should rise above techno-friendly education and environment. Nonetheless, this perspective interprets technology as neutral until it is applied to commercial markets. What is mind boggling is the litany of initiatives that have raised critical questions such as whether or not the $100 \$$ Laptop Project, the One Laptop per Child Program, the No Child Left Behind Act, the Knowledge Is Power Program, or similar initiatives have been successfully finalized. If not, who received the benefits (Cristia et al, 2012)? Thus, multicultural technology is seen to 
be insignificant because applications do not concern societies but professional use. Even though ostensibly meritocratic, technological determinism is fundamentally a reproduction of the techno-social hierarchy; most ethnic societies are imagined to find professions at the worse end of the market. Some matters can equally hand out emancipatory ends by assuming auxiliary utilitarian ends, such as technological applications and its programming mechanisms. No constitutional control exists on adopting TSIs. This leaves open the windows of risk and contingency (for other plausible opportunities). In the literature, most definitions of values are shadowy and inconclusive. A wide variety of theories are found to have been applied and a wide variety of enquiries to have been raised within the study of values. Although, many scholars have attempted to conceptualize the concept of values, they have furthermore also limited themselves as though the concept should be understood as simultaneously enlarging and transforming. "Every question about what to study and how to study it becomes an ethical opening; every decision entails profound responsibility. The whole notion of academic ethics is simultaneously enlarged and transformed" (Gibson-Graham, 2008, p. 620). In definitional terms, Graeber deeply clarifies that:

1. "Values" in the sociological sense are conceptions of what is ultimately good, proper, or desirable in human life. 2. "Value" in the economic sense is the degree to which objects are desired, particularly, as measured by how much others are willing to give up to get them. 3. "Value" in the linguistic sense, which goes back to the structural linguistics of Ferdinand de Saussure (1966), might be most simply glossed over as "meaningful difference." (2001, pp. 1-2).

Graeber further argued values to exactly mean what is desirable (what ought to be wanted) and its effects on human practices; nevertheless, there is always the issue of determining justifiable and understandable value, and so there is rationalism.

Rationality is .... not only in ages in which it easily prevails, but also, and even more, in those less fortunate times in which it is despised and rejected as the vain dream of men who lack the virility to kill where they cannot agree. (Russell, 2004, p. 68).

The difficulty thus takes for granted the outline of which side should be taken? When we prefer a definite side, have we then with certainty defined our value and as such our morality? We must assume the moral arrangement that (value) is inevitably associated with the interests of the technological assumptions that we have to certainly maintain. But facing this primary judgment, we should not assume any moral arrangement at all, provided we can open ourselves before the moral practic- 
es of our technological world. But this, indeed, is an essential prerequisite for building any awareness and sensible decision concerning rivaling moral arrangements such as stopping surveillance governance. From the time when a defined decision being moral merely corresponds to some formerly established moral system, our primary decision may be no moral judgment whatsoever, such as privacy versus security. Yet it may be an academic decision. For as techno-social academicians, we are able to witness what is going to take place. We are able to perceive that the techno-social determinism and its arrangement of morals are being forced to withdraw and that the concerns of Neo-Luddism and its new arrangement of morals are being shaped to rise so that the new life cycle is concerned with new moralities such as Technorealism. We have perhaps noticed this progression to be inevitable. Resisting it would be risky. Apologists of the world orders and their moral ideas of justice and injustice would become more dangerous by-products of techno-social and historical developments. "Norms are man-made in the sense that we must blame nobody but ourselves for them; neither nature, nor God. It is our business to improve them as objectionable" (Popper, 1966, p. 67). In this regard, technological determinism is not objectionable due to the fact that it has no certain value at all. Indeed, everything should depend on its context. If technology represents a significantly malleable notion in the contemporary world, should we take sides to state that technology is a public or private good and/or a common or individual good, or must it be a social good? Nevertheless, whether or not the value of technology has hitherto been applauded to stay in a state of shadows and obscurity, without any helpful assessments being approved to lay its contents before the public, and been protected from the various concerns to which it is actually responsible and accountable is unclear.

Technology has been developed by the public and then lent to the Giant (private power). What they want to do first is corporate transaction (they have a close system with private tyrannies), and the rest is all about marketing services (turning people into passive consumers, you and a means). That is the system at work "...and then you won't have to worry about the threat of democracy" (Chomsky, 1997).

According to Chomsky, a noticeable disadvantage in this system of technological determinism is the actual provision of whether or not the technological master (e.g., Giant) should verify what goods are to be formed and that everybody is bound to execute the work assigned by the master. In this there is no actual preference for occupation, and the tyranny of a divided nation's master (e.g., government) would be surpassed by the tyranny of a greater complex master among the officers of the 
giant's master. To commence with, no one forever recognizes a society whose desires have all been satisfied, which literally implies that innovation and technology are relentlessly leading us into a freshening ground of pleasure that culminates in a perpetual separation of singular desires. To satisfy these desires is the spring to almost all production and consumption. Thus there can be no end to assembling what originated from the surplus of desired commodities. The limit of technology is thereby never satisfied with consuming nor producing power. Nevertheless, in the current TSIs, "Courts are disabled, legislatures pathetic, and code untouchable. That is our present condition. It is a combination of these elements that is deadly in need of action-a mix that guarantees that little good gets done" (Lessig, 2006, p. 324).

"Democracy must be born anew in every generation, and education is its midwife" (Dewey, 1980, p. 139). Because each generation has its own particular variables, expectations, and variances within its own particular interests, it has to face its own unique struggles, exertions, and even its own dilemmas. Therefore, each generation must pursue its own history of previous generations for its own posterity. Nevertheless, the burgeoning emerging technology differs from the other entry points of production, labor, and market because it is uniquely susceptible to indefinite augmentation. Its extent is absolutely unrestricted, as well as the extent of its more dynamic kinds of unrestricted stills (e.g., no tipping point). The extent of production capable of being increased on any known portion of technology is also obviously indefinite. This unrestricted quantity of technology and its unrestricted productiveness are genuine inhibitions to augmenting production due to the current uncertain valueless-ness it has. Has it become totally prone to inevitable failure (e.g., self-destruction) in the long run? Being unrestricted in production by possessing technology is not like the difficulty of passing a wall that stands permanently at one particular point; it suggests no difficulty in movement short of stopping it completely. This general principle of technological acceleration is the most significant proposition in the knowledge-based economy. Were the principle different, nearly all observable facts about the production and allocation of capital would be other than what they are. Considering the assertion that being disabled by appropriate technology means becoming a human without hindrance, technology has indeed defined human, or being human. In this sense, how far we can go and still be human is not the most crucial matter in this study, even though matters of techno-social interactions could play a role in our forgetting our global, political, and economic natures and realities. So we perhaps should be purely philosophical by reminiscing on the first Luddite, Diogenes of Sinope, in order to remember our antecedents to TSIs. 
Only when no technology remains to be destroyed, such as either from reserves or the lower quality that needs a significant increase of value to make their cultivation marketable, can the appropriation of developed nations' elevated technology by any undeveloped nations become beneficial, except perhaps in the instant locality of nations where reducing the cost of our lives may balance out great weakness in return for technology itself. The most noticeable part of this is the evolution of technological knowledge, skills, and inventions. Enhanced technological evolution has two types: (a) when developed nations facilitate technology to submit a highest absolute product without equally augmenting it through human capabilities, and (b) when there are others who have no power to escalate production but have a deteriorating human force and the expenditures given by it. Thus no potential improvement exists in the mechanisms of technological production that do not exist in one or more forms implementing an antagonistic pressure on the principle of deteriorating returns in the technological worlds. Nor do only technological improvements have this result. Improvements in administration and almost each kind of ethical and shared progression function in the same method. We may say the same of developments in education. To resume, all ordinary causes that are incomplete in their extent are not only incomplete in their final creative power, but also incomplete long before that power has destabilized to the extreme; they give way to any further burden on increasingly harder conditions. Even where the need for production is well-established, people must be held in reserve by unrestricting their lives from technology. In this sense, almost all burgeoning knowledge is being pushed ahead by technological means; the technology refers to being looked upon as the main characteristic in the value of transaction. Because this does change hands; humans fail to notice the devastation that has become a reality in the case of technological singularity. With the simple transference of technology, they believe happiness also has simply been handed over from spendthrifts to others. But this would merely confuse technology with happiness and freedom. The happiness and freedom being smashed are not technology; however, society is worse off communally by degrees.

Thus, what next? "If it were sufficient to love, things would be too easy. The more one loves the stronger the absurd grows. It is not through lack of love that Don Juan goes from woman to woman to woman" (Camus, 1955, p. 45). Hypothetically and metaphorically speaking, if we approach technology as an enlivened Don Juan, which is a grave realism to desire nation sleeping with nation and individual with individual when anyone can afford (be offset) to, TSIs lead (force) us to become another (governed) cheerful sentimentalist, a modern absurd human who is 
"born out of this confrontation between the human need and the unreasonable silence of the world" (p. 32). In this sense, the modern absurd human is unable to deal with and in fact even awkward in dealing with instinctive human values (e.g., happiness) and the meaning of life (e.g., freedom) due to the unreasonable noise from techno-worlds (e.g., governed techno-social struggles). As such, Don Quixote, a fanciful idealist, is incapable of seeing things as they are. "Absurd Man? He who, without negating it, does nothing for the eternal... The first teaches him to live without appeal and to get along with what he has; the second informs him of his limits" (p. 43). According to this standpoint, a pertinent matter is to authorize humans to engage technologically with their techno-social context in an empowering manner. It teaches a difficulty posed by technology, how to impart human rights to their knowledge. All this may be offered using a progressive technological perspective. Nevertheless, where the public gets ahead of this is all the way through the engagement of critical judgment through the public's questioning of technological content; socially applicable struggles and circumstances are employed for techno-social human congruence and engagement. For the public, this fundamental technology is a means to increase human ability and techno-social engagement among humans. The literature acknowledges much of the earlier perspectives of TSIs yet inserts further techno-socio-political and philosophical aspects. According to Charles L. Black, the angle of inclination of TSIs' incommensurability is that:

...almost everybody living under a government of limited powers must sooner or later be subjected to some governmental action which as a matter of private opinion he regards as outside the power of government or positively forbidden to government. A man is drafted, though he finds nothing in the Constitution about being drafted. (1960, p. 35)

\section{Epilogue}

From the above arguments, the concern of Technorealism is that because of improved technology, the giants have greater governance power over the masses; and because individual effort will herein after be essential, the masses will be unimportant in ways that ineffectively burden the technological society. If giants and their allies are unfeeling, they may merely make a decision to harm the masses of humankind. If they have humanist values, they may exercise propaganda or other sociological systems to occupy the role of great shepherds for humanity. In this sense, we have to argue more about the political sociology of TSIs. In this sense, Neo-Luddism, and as such Technorealism, is mistakenly thought of as encompass- 
ing two missions: a destruction of modern existing values and a construction of new traditional ones. But in this vein, Techno-utopianisms (Nietzschean thoughts) or at least a dominated technological determinism postulate that everything must be advanced or be destroyed. The challenge becomes noticeable if we consider the focus of the matter: its values. To destroy one set of values comes into view as assuming another set from which one has already destroyed. But determinists reject even this.

For since each generation has its own troubles and problems, and therefore its own interests and its own point of view, it follows that each generation has a right to look upon and re-interpret history in its own way, which is complementary to that of previous generations. (Popper, 1966, p. 462).

Unsurprisingly, Technorealists raise their own set of values. But not only do they invite others to follow them in accepting their values, they also try to get others to re-question the value of the values that they have intuitively accepted. So it is not the aim of Technorealism to initiate a new value mechanism as such but to offer dissimilar perspectives. It is a challenge of existing values, not a structuring of new ones where the factualness of all our existing values has not been called into question. It is when this negation turns out to be noticeable that this lack of value turns into a problem and commences to feedback on itself. Under the appearance of active determinism, values are destroyed instead of being approved to worsen and become naturalized. In this regard, it purifies. It is not a construction of new values, but the ruination of the old. It presents a fresh standpoint and unlocks new prospects because without definitive values, superior technology is not always intended to be equivalent to superior living. "The economist needs the three great intellectual faculties: perception, imagination, and reason. And most of all, he needs imagination" (Marshall, 1890, p. 43). Once the discipline's systems of isolation are recognized in this way, then technology can be asserted to be impartial and neutral (value free). Values are borne out of systems that establish what is permissible. Inclinations, options, techno-social connotations, and all other similar values-jargon are all removed by precise and objective systems. In fact, the values lay beneath the alternative of the systems assembling them as practically unchallengeable. For by legitimizing only the official stage of dialogue as technology, it reduces in importance the issue of values to a dominion beyond that of technology. Technology is a complex matter of both teaching and learning. One of the motivations why this is so is because technology is hierarchical and adaptive to innovative exertion, which frequently depends on adequate consideration of one or more of the sections of 
exertion that are left in front. Consequently, on the surface, the literature on TSIs mirrors the perspective of philosophical Utilitarianism. On the contrary, however, it is definitely technological determinism, which hides its meaninglessness and irrationality so as to become Modern Absurdism. Absurdism is thereby willing to reveal its own consequences, revolts, freedoms, and passions unknowingly by accepting and knowing without accepting. Metaphorically speaking, there is no way to run away from current and future controllers (technocrats of technological determinism) in order to not be in the theater of the Don Juan Society, in which the total attempt is made to have all of us (absurdists) be governed to sleep with the all-general purpose of computing (modern promiscuity) without taking any peculiar postmodern moral objectives (e.g., stop surveillance governance). Nevertheless, we should remember that "The absurd does not liberate; it binds. It does not authorize all actions. 'Everything is permitted' does not mean that nothing is forbidden" (Camus, 1955, p. 44).

\section{References}

Black. L. B. (1960). The people and the court. New York, NY: Macmillan

Bogard, W. (1996). The simulation of surveillance: Hypercontrol in telematic societies. Cambridge, MA: Cambridge University Press.

Boyle, J. (2008). The public domain: Enclosing of the commons of the mind. New Haven, CT: Yale University Press.

Butler, S. (1863). The book of the machines. Moscow, Russia: Dodo Press

Camus, A. (1955). The myth of Sisyphus.

Chomsky, N. (1997). Internet and Bill Gates. Retrieved from http://www.youtube.com/watch?v=yP1e7u0C5K8

Cristia, P. J., Ibarrarán, P., Cueto, S., Santiago, A., \& Severín, E. (2012). Technology and child development: Evidence from the one laptop per child program. Retrieved from http://idbdocs.iadb.org/wsdocs/getdocument.aspx?docnum $=36706954$

Dewey, J. (1980). The middle works: 1899-1924. Carbondale, IL: SIU Press.

Doctorow, C. (2013). Information doesn't want to be free. People do. Retrieved from https://medium.com/@aemtn/ information-doesnt-want-to-be-free-people-do-b15a249a4f0

Ellul, J. (1964). The technological society. J. Wilkinson (Trans.). New York, NY: Knopf.

Gates, B. (1996). The road ahead. New York, NY: Penguin.

Gibson, K. (2008). Diverse economies: Performative practices for 'other worlds.' Human Geography, 32(5), 613632.

Glendinning, C. (1990). Notes towards a Neo-Luddite manifesto. Untre Reader, 38(1), 50-53.

Graeber, D. (2001). Toward an anthropological theory of value: The false coin of our own dreams. Basingstoke, UK: Palgrave MacMillan

Gustave, L. (1896) The crowd: A study of the popular mind. London, UK: Tombstone Press.

Haraway, D. (1985). A cyborg manifesto: Science, technology, and socialist-feminism in the late twentieth century. Socialist Review.

Heidegger, M. (1977). The question concerning technology, pp. 3-35. 
Hughes, P.T. (1994) .Technological momentum. In M. R. Smith and L. Marx (Eds.), Does technology drive history? The dilemma of technological determinism. Cambridge, MA: MIT Press.

Lanier, J. (2012). Learning by experience \& play. Retrieved from http://www.youtube.com/watch?v=F9eFZpdSeRU the time is $28-29$.

Lessig, L. (2006). Code version 2.0. New York, NY: Basic Books.

Luppicini, R. (2008b). Introducing technoethics. In R. Luppicini and R. Adell (Eds.), Handbook of research on technoethics (pp. 1-18). Hershey, PA: Idea Group Publishing.

Marshall, A. (1920). Principles of economics (8th ed.). London: Macmillan and Co.

McCluskey, K.E. (1998). Defining Technorealism. Retrieved from: http://cyber.harvard.edu/technorealism/

McDermid, D. (1996). Pragmatism. In The Internet encyclopedia of Philosophy (IEP).

Morozov, E. (2011). The net delusion. London: Penguin Group.

Nozick, R. (1974). Anarchy, state, and utopia: Blackwell. Oxford, UK \& Cambridge, USA.

Oppenheimer, T. (2004). The flickering mind: Saving education from the false promise of technology. New York, NY: Random House Publishing Group.

Organisation for Economic Co-operation and Development (1996). The knowledge-based economy. Paris, France.

Pool, I. S.. (1983). Technologies of freedom: On free speech in an electronic age. Fellows of Harvard College.

Popper, R. K. (1962). The open society and its enemies.

Proke冈ova, E. (2011, December 8-9). What is moral agency of artificial agents? Beyond AI: Interdisciplinary aspects of artificial intelligence. Proceedings of extended abstracts presented at The International Conference beyond AI 2011. Pilsen, Czech Republic.

Russell, B. (2004). In praise of idleness and other essays. Abindon-on-Thames, UK. Routledge.

Sale, K. (1996). America's new Luddites. Retrieved from http://mondediplo.com/1997/02/20luddites

Sourin, A., Sourina, O., \& Prasolova-Førland, E. (2006). Cyber-learning in cyberworlds, Journal of Cases on Information Technology, 8(4), 55-70

Tiqqun . (2010). The cybernetic hypothesis. The Anarchist Library Anti-Copyright

Wiener, N. (1964). God and golem, Inc.: A comment on certain points where cybernetics impinges on religion. M.I.T. Press, Cambridge, MA.

Williams, R., \& Edge, D. (1996). The social shaping of technology. Research Policy, 25, 856-899.

Winner, L. (1989). Conflicting interests in science and technology studies. Technology in Society, 11, 433-438.

Winston, B. (1998). Media, technology \& society: A history from the telegraph to the Internet. London, UK: Routledge. 
